\title{
Economic valuation of forest conservation: the relative contribution of the variables affecting forest degradation in Western Mexico
}

Armonía Borrego*

Rebeca Hernández

\begin{abstract}
Participation of forest communities in forest conservation management could increase the potential to achieve the goal of reducing emissions from forest degradation and mitigate climate change effects. Forest conservation requires a change (or cease) in economic activities that are traditionally practiced by forest communities which contribute to forest degradation. In this study we estimate the minimum amount of compensation required to forgo the main activities contributing to forest degradation. In order to do so, data collected from interviews made to farmers in Western Mexico were used. Results from the conditional logit model show the relative importance the interviewed farmers give to the traditional agricultural system, cattle grazing and lumber extraction (firewood and construction posts). Without proper compensation, restriction of these activities would affect the livelihood of forest communities and hold back farmers willingness to participate, conditioning the success of forest conservation. These results identify some challenges for international climate change mitigation policies, such as reduction of emissions from deforestation and forest degradation (REDD+).
\end{abstract}

Keywords: Tropical dry forest, forest conservation, forest income, forest communities, choice experiments, REDD+

\section{Valoración económica de la conservación forestal: la contribución relativa de las variables que afectan a la degradación forestal en el occidente de México}

\section{Resumen}

La participación de las comunidades forestales en las actividades de conservación de bosques podría aumentar las posibilidades de alcanzar el objetivo de reducir las emisiones causadas por la degradación forestal y mitigar los efectos del cambio climático. La conservación de bosques requiere un cambio (o renuncia) en algunas actividades económicas que tradicionalmente se practican en las comunidades forestales y que contribuyen a la degradación de los bosques. En este estudio se calculan las compensaciones mínimas asociadas a la renuncia de las principales actividades asociadas a la degradación forestal. Para ello, se utilizan datos provenientes de entrevistas con campesinos en la región occidente de México. Los resultados del modelo logit condicional muestran la importancia relativa que los campesinos entrevistados otorgan al sistema agrícola tradicional, pastoreo de ganado y extracción de productos maderables (leña y postes para construcción). Sin una adecuada compensación, las restricciones de estas actividades afectarían al sustento de las comunidades forestales y frenarían la disposición a participar de los campesinos, condicionando el éxito de la conservación forestal. Estos resultados permiten identificar algunos desafíos para las políticas internacionales de mitigación del cambio climático como el de reducción de emisiones por deforestación y degradación forestal (REDD+).

Palabras clave: Bosque tropical, conservación de bosques, ingresos forestales, comunidades forestales, experimentos de elección, REDD+.

\footnotetext{
Universidad Nacional Autónoma de México, Centro de Investigaciones en Geografía Ambiental. Morelia, Michoacán, México.

*Corresponding author: armoniab@gmail.com
}

Received: April 29, 2019.

Accepted: September 20, 2019. 


\section{Introduction}

Over the past decades, forests have been a special object of study for the scientific community as well as the main component of some international policies due to their capacity to fixate atmospheric carbon.

Findings from research carried out during past decades have recognized that the participation of local communities in the management and use of forests is essential to succeed in forest conservation (Johannesen, 2005). Current conservation measures seek to directly involve forest communities in international initiatives implemented in their localities; however, evidence shows that these measures have not had the awaited success to reach the conservation goals (Johannesen, 2005; McShane \&Wells, 2004).

Success in forest conservation requires a change in farmers' behavior that depend on forest goods to maintain their livelihoods. International policies -such as the Reducing Emissions from Deforestation and Forest Degradation REDD+- put forward a compensation for those who use the forest in exchange of these restrictions (or cease) on the use of forests.

Some researchers have explored the contribution of forest resources to mitigate rural poverty and their importance as livelihood for the inhabitants in rural zones (Angelsen et al., 2014; Campbell \& Luckert, 2002; Vedeld, Angelsen, Bojö, Sjaastad, \& Kobugabe, 2007). Others have analyzed the relative contribution to the incomes of those households involved directly in activities related to forest degradation (Ickowitz, Sills, \& De Sassi, 2017; Morales-Barquero, Borrego, Skutsch, Kleinn, \& Healey, 2015). The scarce amount of studies is due to: 1) the lack of a national and international consensus about the definition of forest degradation; 2) the complexity of identification and measurement of the forest degradation processes; 3 ) the fact that forest degradation is a process that extends rapidly because it is produced when forest resources are being used, therefore it is associated to the activities and everyday practices of forest communities.

This research is focused on measuring the importance or relative contribution through implicit prices and processes associated to forest degradation. Some authors have found that forest degradation as

\section{Introducción}

En las últimas décadas los bosques han sido especial objeto de estudio para la comunidad científica y también el principal componente de algunas políticas internacionales debido a su capacidad para la fijación de carbono atmosférico.

Los hallazgos en las investigaciones de las últimas décadas han reconocido que la participación de las comunidades locales en el manejo y uso de los bosques es fundamental para alcanzar el éxito de la conservación forestal (Johannesen, 2005). De esta manera, las medidas de conservación actuales buscan involucrar directamente a las comunidades forestales en las iniciativas internacionales que se implementan en sus localidades; sin embargo, las evidencias muestran que estas medidas no han tenido el éxito esperado para alcanzar los objetivos de conservación (Johannesen, 2005; McShane \& Wells, 2004).

El éxito de la conservación forestal requiere una modificación en el comportamiento de los campesinos que dependen del aprovechamiento de los bienes forestales para mantener sus medios de subsistencia. Las políticas internacionales -como la reducción de emisiones por deforestación y degradación forestal REDD+- plantean una compensación para los usuarios de los bosques a cambio de esta modificación (o renuncia) en el uso de los bosques.

Algunos autores han explorado la contribución de los recursos forestales para mitigar la pobreza rural y la importancia como medio de subsistencia para los habitantes en las zonas rurales (Angelsen et al., 2014; Campbell \& Luckert, 2002; Vedeld, Angelsen, Bojö, Sjaastad, \& Kobugabe, 2007). Otros, han analizado la contribución relativa para los ingresos de los hogares de aquellas actividades asociadas directamente a la degradación forestal (Ickowitz, Sills, \& De Sassi, 2017; Morales-Barquero, Borrego, Skutsch, Kleinn, \& Healey, 2015). Esta escasez de estudios se debe a que: 1) no existe un consenso sobre la definición de degradación forestal en el ámbito nacional e internacional; 2) la identificación y medición de los procesos de degradación forestal es compleja; 3) la degradación forestal es un proceso que se extiende rápidamente porque se produce en paralelo al uso y aprovechamiento de productos forestales, es decir, 
well as deforestation significantly contribute to carbon emissions in tropical regions and can even exceed the affected area from deforestation (FAO, 2010; Foley et al., 2007; Skutsch et al., 2017).

Recent studies have found that shifting cultivation is associated directly to forest degradation (Angelsen et al., 2014; Hosonuma et al., 2012; Kissinger, Herold, \& Sy, 2012). This study postulates that shifting cultivation, a traditional agricultural system to several forest households in poverty, is a factor that contributes to forest degradation.

The aim of this study is to estimate changes in social welfare regarding willingness to accept, due to potential restrictions on the use of natural resources that provide supplies and income to rural households in Western Mexico. Empirical analysis in this study is carried out by using choice experiments to estimate the associated values to potential changes or restrictions in practicing shifting cultivation, cattle grazing and the use of limber (firewood and posts) in the Ayuquila River Basin, Jalisco. The results show useful information for decision makers and environmental managers, because they provide a realistic view of some socioeconomic implications that could be expected from REDD+ initiatives that offer a payment per ton of stored carbon.

\section{Materials and methods}

\section{Study area}

The case study is located in the Ayuquila River Basin (Figure 1), which has an area of $9864 \mathrm{~km}^{2}$ and it is located in Western Mexico, in the states of Jalisco and Colima, with a riverbed towards the Pacific, between $102^{\circ} 56^{\prime}$ and $104^{\circ} 35^{\prime}$ west longitude and $18^{\circ} 40^{\prime}$ and $20^{\circ} 29^{\prime}$ north latitude. In the interior of the basin the municipalities located in the Junta Intermunicipal de Medio Ambiente de la Cuenca Baja del Río Ayuquila (JIRA, acronym in Spanish) with similar characteristics were taken as a sample, with altitudinal ranges between 680-1 $800 \mathrm{~m}$, where tropical forests and rainforests grow in a sub-humid warm climate with a mid-annual temperature of $22.5^{\circ}$. The rainy season goes from June to October with a mid-annual precipitation of $813 \mathrm{~mm}$ and the dry season goes from November to May. está asociada a las actividades y prácticas cotidianas de las comunidades forestales.

Esta investigación se centra en la medición de la importancia o contribución relativa a través de los precios implícitos y de los procesos asociados a la degradación forestal. Algunos autores han encontrado que la degradación forestal al igual que la deforestación, también contribuyen de una manera importante a las emisiones de carbono en las regiones tropicales y que incluso podría superar la superficie afectada por deforestación (FAO, 2010; Foley et al., 2007; Skutsch et al., 2017).

Investigaciones recientes han encontrado que la práctica del sistema agrícola roza-tumba-quema se asocia directamente a la degradación forestal (Angelsen et al., 2014; Hosonuma et al., 2012; Kissinger, Herold, \& Sy, 2012). Este estudio parte del supuesto de que el sistema roza-tumba-quema, un sistema agrícola tradicional para muchos hogares forestales en pobreza es un factor de degradación forestal.

El objetivo de este estudio es estimar los cambios en el bienestar social en términos de disposiciones a aceptar, debido a potenciales restricciones en el uso de recursos naturales que proveen de insumos e ingresos a los hogares rurales en la región occidente de México y que causan la degradación forestal. El análisis empírico en esta investigación se realiza a partir de una aplicación de modelos de elección para calcular los valores asociados a cambios potenciales o restricciones en la práctica del sistema agrícola roza-tumba-quema, el pastoreo de ganado y el uso de productos maderables (leña y postes) en la cuenca del Río Ayuquila, Jalisco. Los resultados arrojan información útil para tomadores de decisiones y gestores ambientales, porque permite tener un panorama realista de algunas implicaciones socioeconómicas que pueden esperarse a partir de las iniciativas REDD+ que ofrecen un pago por tonelada de carbono almacenado.

\section{Materiales y métodos}

\section{Área de estudio}

El caso de estudio se localiza en la cuenca del Río Ayuquila (Figura 1), que tiene una superficie de $9864 \mathrm{~km}^{2}$ y se localiza en el Occidente de México, 


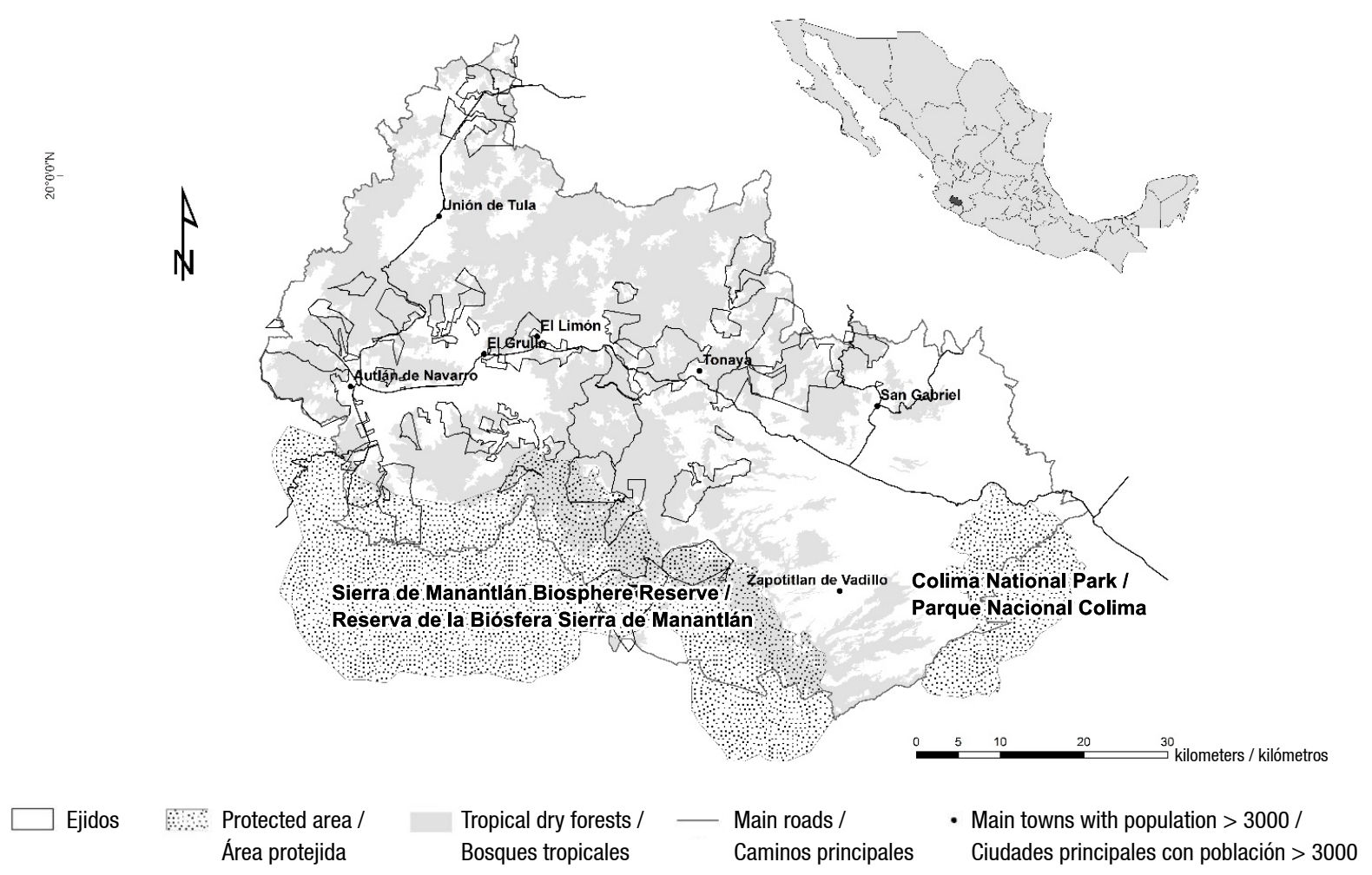

Figure 1. Map of the study area located in the Lower Basin of the Ayuquila River, Jalisco.

Figura 1. Mapa del área de estudio situado en la Cuenca Baja del Río Ayuquila, Jalisco.

The degree of marginalization of these municipalities goes from mid to low level and with high migration intensity (IIEG, 2010). The main economic activities are retail commerce, services and farming activities, although the last two have decreased during the last decade.

According to the Índices Municipales de Medio Ambiente which take into consideration conditions of pressure, state and response', the study area has a mid-high category above 53 percentage points (IIEG, 2010). Regarding vegetation coverage of the study area, rainforests occupy $41.6 \%$, forests $16.95 \%$ and agriculture $30.6 \%$, the rest corresponds to other types of vegetation and human settlements.

The type of land tenure in the study area is mainly formed by small landholders and ejidos. Shifting cultivation (itinerant agriculture or coamiles, also

'Based on the conditions of water supply coverage, drainage coverage, protected natural areas, recovering, generation of solid wastes, deforestation, groundwater exploitation, forest coverage. Higher values indicate higher pressure and overexploitation of natural resources. en los estados de Jalisco y Colima, con vertiente en el Pacífico, entre los $102^{\circ} 56^{\prime}$ y $104^{\circ} 35^{\prime}$ longitud oeste y los $18^{\circ} 40^{\prime}$ y $20^{\circ} 29^{\prime}$ latitud norte. Al interior de esta cuenca se tomaron como muestra los municipios localizados en la Junta Intermunicipal de Medio Ambiente de la Cuenca Baja del Río Ayuquila (JIRA) con características similares, con rangos altitudinales entre los 680-1 $800 \mathrm{~m}$, donde crecen bosques tropicales y selvas, en clima cálido subhúmedo con temperatura media anual de $22.5^{\circ} \mathrm{C}$. El temporal de lluvia es de junio a octubre con una precipitación media anual de $813 \mathrm{~mm}$ y la época de estiaje va de noviembre a mayo.

El grado de marginación de estos municipios va de un nivel medio hasta bajo y con alta intensidad migratoria (IIEG, 2010). Las principales actividades económicas son el comercio al por menor, servicios y actividades agropecuarias, aunque estas últimas han tenido un decremento en la última década.

De acuerdo con los Índices Municipales de Medio Ambiente que consideran condiciones de presión, 
known as milpa) is practiced on both types of tenure that predominate in the study area especially on the surface covered by tropical dry forests. In the study area a considerable amount of coamil producers are avecindados ${ }^{2}$ who lease land in the spring-summer season and cultivate the land with the least amount of economic investment, which give rise to benefits throughout the year due to the products obtained from the coamil to support their families. Observations during fieldwork showed that the proportion of ejidatarios that practice this agricultural system represent a minor proportion compared to the group of avecindados, although there is not an official record indicating the proportion of each group.

\section{Characterization of the traditional activities}

\section{in the study area.}

Hereunder is a description of three common economic activities practiced in the study area which contribute to forest degradation.

\section{a) Shifting cultivation cycle (coamil)}

The term coamil or cuamil has a Nahuatl etymological root, cuahuitl which means tree and milli heritage and they refer to an area destined for agricultural crops between trees, although some people who carry out this practice associate it with the use of a tool named coa which is used to till and the prefix milpa which is the maize plant.

Cultivating a coamil is a traditional activity carried out mainly by household members for their livelihood, each member collaborates in a phase of the process. It is frequently found in rural regions, on irregular areas of tropical and temperate forests in which, agricultural technified machinery is unattainable because of the topographic characteristics of the land. Maize is the main product they want to obtain (although in some cases they include other crops such as beans and squash), although during the process they also obtain other products which represent savings or an additional income for the household.

2 People who have resided in the ejido for more than a year and have been recognized by the asamblea ejidal as such. In the study area, avecindados tend to carry out by majority the activities in the coamil from opening and cultivating it to harvesting. estado y respuesta', el área de estudio tiene categoría media-alta por arriba de los 53 puntos porcentuales (IIEG, 2010). Respecto a cobertura vegetal del área de estudio, las selvas ocupan $41.6 \%$, los bosques 16.95 $\%$ y la agricultura $30.6 \%$, el resto corresponde a otro tipo de vegetación y asentamientos humanos.

El tipo de tenencia de la tierra en la zona de estudio se compone principalmente de pequeña propiedad y ejidos. El sistema agrícola de rozatumba-quema (es decir, agricultura itinerante o coamiles) se practica en los dos tipos de tenencia que predominan en la zona de estudio, sobre todo, en la superficie cubierta por selva baja. En el área de estudio una gran proporción de productores de coamil son avecindados ${ }^{2}$ que solicitan en préstamo el terreno para aprovechar el ciclo primaveraverano y cultivar la tierra con la mínima inversión económica, pero que representa beneficios a lo largo de todo un año por los productos que se obtienen a partir del coamil para el sustento de su familia. Las observaciones en trabajo de campo permitieron advertir que la proporción de ejidatarios que practican este sistema agrícola representan una proporción menor comparado al grupo de avecindados, aunque no existe un registro oficial que indique la proporción de cada grupo.

\section{Caracterización de las actividades tradicionales en la zona de estudio}

A continuación, se presenta una descripción de tres actividades económicas habituales que se practican en la zona de estudio y que contribuyen a la degradación forestal.

\section{a) Ciclo y cultivo del sistema agrícola} roza-tumba-quema (coamil)

El término coamil o cuamil tiene raíz etimológica náhuatl, cuahuitl que significa árbol y milli, heredad y se refieren a una superficie destinada a cultivos

${ }^{1}$ Con base en las condiciones de cobertura de abastecimiento de agua, cobertura de drenaje, áreas naturales protegidas, recuperación, generación de residuos sólidos, deforestación, explotación de acuíferos, cobertura forestal. A valores más altos indica una mayor presión y sobreexplotación de los recursos naturales.

\footnotetext{
${ }^{2}$ Personas que han residido por más de un año en el ejido y que han sido reconocidas por la asamblea ejidal como tal. En la zona de estudio los avecindados suelen realizar por mayoría las actividades en el coamil, desde la apertura y el cultivo hasta la cosecha.
} 
Cultivating in coamiles is directly related to the rainy season, which goes from June to October in the study area. The opening of a coamil starts with selecting a plot of land, which must have suitable humidity and soil quality conditions for the development of the crops. The dimensions of a coamil depend mainly on three characteristics: i) the capacity or human effort of farmers; ii) the amount of time they want/can invest; iii) the yield they want to obtain to support their family; so there can be coamiles of half a hectare or larger than five hectares. From January to February the farmer starts with cutting down trees to uncover the land that will be cultivated, using simple tools such as axes, machetes, casangas, güingos and wooden hooks they get from the same vegetation. In this initial phase, lumber products are obtained, such as posts, wood and firewood; the branches and vegetation with no extractive use are accumulated in piles inside the coamil and are kept there until they dehydrate. Later on, in March, April and May, the branches from slashing are burnt to clean the cultivating area and to "kill the pests on the ground". As a result from burning, the soil's acidity is balanced and the number of pests that could affect the crops decrease.

The rainy season starts in June and ends at the end of the same month with the filtrated soil that has retained enough water, available for the farmer to sow. With the assistance of a tool named coa, the farmer moves forward on the contour lines digging holes of 10 to 15 centimeters deep where the previously selected seeds are sown. In the second half of July and beginning of August after the seeds have germinated, the weeding phase begins which consists of cutting shoots and weeds by hand or with a tool known as rosadera and leaving them near the cultivated plant to retain the humidity; however, during the past years some producers use agrochemical pesticides they apply with spray pumps over the weeds because it is faster and efficient to eliminate them. This is a recent practice which obeys to the adaptation of farmers to the rapid growth of weeds in current years.

When a coamil is new or recently opened, the farmer does not need to apply pesticides because the soil has enough nutrients and organic matter for plants to have a good development; on the contrary, agrícolas en medio de árboles, aunque algunas personas que realizan esta práctica lo relacionan con el uso de la herramienta llamada coa que se utiliza para la labranza y el prefijo milpa que es la planta del maíz.

La práctica de cultivo en coamil es una actividad tradicional que se realiza principalmente por un núcleo familiar para su sustento, donde cada miembro colabora en alguna fase del proceso. Es frecuente observarla en regiones rurales, en superficies accidentadas de bosques tropicales y templados donde el uso de maquinaria agrícola tecnificada es inasequible debido a las condiciones topográficas del terreno. El producto que se busca obtener es principalmente maíz (aunque en algunos casos incluyen varios cultivos como frijol y calabaza), aunque en el proceso se obtienen implícitamente otros productos que para el usuario representan un ahorro o un ingreso adicional para el hogar.

El cultivo en coamiles está relacionado directamente con el ciclo de lluvia, que para esta área de estudio es de junio a octubre. La génesis de un coamil se da con la elección del terreno, el cual debe tener las condiciones de humedad y calidad de suelo adecuadas para el desarrollo de los cultivos. Las dimensiones del coamil dependen principalmente de tres características: i) la capacidad o el esfuerzo humano del campesino; ii) el tiempo que se quiere/puede invertir; iii) el rendimiento que se espera obtener para el sustento de la familia; así pueden existir coamiles de media hectárea o mayores de cinco hectáreas. Entre los meses de enero y febrero el usuario procede a desmontar o quitar el arbolado para descubrir la superficie a cultivar, usando herramientas simples como hachas, machetes, casangas, güingos y ganchos de madera que obtienen de la misma vegetación. En esta etapa inicial se aprovechan productos maderables como postes, madera y leña; el ramaje y la vegetación que no son de utilidad extractiva se acumulan en montones al interior del coamil y se reservan hasta que se deshidraten. Posteriormente en los meses de marzo, abril y mayo, se procede a quemar el ramaje resultado del desmonte con la finalidad de limpiar el área de cultivo y'matar las plagas del suelo'. El efecto que resulta de la quema es el balance en la acidez del suelo y disminución en la cantidad de patógenos que pudieran afectar los cultivos.

El temporal de lluvia inicia en el mes de junio y es a finales del mismo mes con el suelo filtrado que ha 
when the coamiles have been used in previous years, the amount of nutrients in the soil decreases, so they usually let the land lie fallow for a maximum of five years- continuous crop cycle. Therefore the farmers let the coamil 'fallow' for a similar period of time, that is to say, if the plot is worked for five continuous years, they let the land lie fallow for approximately five continuous years. A producer that sows in a previously worked coamil needs to invest more time and money in the fertilizing phase which is carried out exactly after weeding.

Harvest is carried out in two stages: in September and October the first harvest of the dry fruit is made, the ears of corn are cut manually and are put into sacks. These fruits will be used as food for the household for several days; when there is a surplus, it will be sold to contribute to the family's income.

The second harvest stage is carried out between November and December, when the crop has reached maturity, the grain can be extracted. The farmer prepares big baskets (one basket has the capacity of up to $1 \mathrm{~m}^{3}$ ) depending on his capacity, he will tie it up or carry it on his back; with the help of a small tool made of steel called piscalón he will only extract the ear of corn, without leaves nor plant. Once he has filled the baskets, he will take them to storage or the barn where he and his family will determine the amount destined for their subsistence and the one they will reserve for sale.

\section{b) Cattle grazing cycle}

Crop residue (stems, leaves and corncob) has a high forage nutritional content, hence its use is considered to be part of the coamil production system. The quality of the fodder is better when it is fresh; so the fodder is used immediately after maize is harvested.

Because the farmer sowing a coamil is not always the owner of the land and does not always have cattle, the use of the crop residue requires a negotiation between the actors involved in diverse scenarios; there are four types farmers in the study area:

i) the farmer sowing a coamil owns the land and has cattle. The fodder is used to feed his own cattle.

ii) the farmer sowing a coamil owns the land, but does not have cattle. In this case, the fodder is retenido suficiente agua, cuando el usuario se dispone a sembrar. Con el apoyo de la herramienta llamada coa, el usuario avanza sobre las curvas de nivel cavando hoyos de 10 a 15 centímetros de profundidad, donde siembra las semillas previamente seleccionadas. En la segunda parte del mes de julio y principios del mes de agosto luego que las semillas han germinado, se inicia la fase de deshierbe, que consiste en cortar los brotes y la maleza con las manos o con una herramienta conocida como rosadera y dejarlos cerca de la planta cultivada para conservar la humedad; sin embargo, en los últimos años algunos productores utilizan herbicidas agroquímicos que los aplican con bombas aspersoras sobre la maleza por la rapidez y eficiencia para eliminarla. Esta es una práctica reciente que obedece a la adaptación de los campesinos al rápido crecimiento de la maleza en años recientes.

Cuando el coamil es nuevo o 'recién abierto', el campesino no requiere aplicar fertilizantes pues el suelo tiene suficientes nutrientes y materia orgánica para el buen desarrollo de la planta; caso contrario, cuando se trata de coamiles usados en años anteriores, la cantidad de nutrientes en el suelo disminuye en cada ciclo, por lo cual suelen dejar un máximo de cinco años-ciclo de cultivo continuo. Por ello, los usuarios dejan 'descansar' el coamil por un periodo similar al utilizado para su recuperación, es decir, si se trabaja cinco años continuos, lo dejan descansar aproximadamente cinco años continuos. El productor que siembra en coamil previamente trabajado requiere invertir más tiempo y dinero en la fase de fertilización que será justo después del deshierbe.

La cosecha se da en dos tiempos: en el mes de septiembre y octubre se logra la primera cosecha en forma de fruto fresco, se cortan los elotes de manera manual y se introducen en un saco contendedor. Estos frutos serán el alimento del hogar por varios días, incluso si hubiera excedentes se venderán para contribuir a la economía familiar.

La segunda etapa de cosecha se da entre noviembre y diciembre, cuando el cultivo ha alcanzado su madurez y puede extraerse el grano. El productor se atavía con canastos grandes (un canasto llega a tener capacidad hasta de $1 \mathrm{~m}^{3}$ ) según su capacidad, lo sujetará y cargará en su espalda; con el apoyo de una pequeña herramienta de acero llamada piscalón extraerá únicamente la mazorca, sin 
sold to cattle owners and the landowner earns an income. The main agreements are usually the lease of the plot for a season -with a fixed price per hectare-, or a fixed price per unit of cattle fed for a six-month grazing period.

iii) the farmer sowing a coamil does not own the land, but has cattle. When negotiating with the owner, the conditions regarding the use of the coamil and the fodder are established, the agreement can be financial (e.g. an established price) or an exchange agreement.

iv) the farmer sowing a coamil does not own it and does not have cattle. In these cases the farmer is only interested in the maize, so the fodder belongs to the owner of the land.

In each case, fodder always represents a direct good or a saving for the landowner. There are two main modalities to utilize the crop residue: 1) when the whole or grinded fodder is taken to the place where the cattle is found (ex situ), or 2) when the cattle is taken to the coamil to graze where the fodder is (in situ). According to our field observations, in situ utilization enables the use of maize residue as food, it also prevents the fast growth of bushes which tend to cover the surface preventing the establishment of weeds, an additional advantage is the manure, which is used as a natural fertilizer for the new crop cycle.

\section{c) Usage of other materials}

The coamiles technique is a livelihood for rural families because the whole cycle of a coamil means using the resources and products in each phase. This translates into satisfying the basic needs of a household, such as food and housing and the surplus of products can give rise to an additional income. For example, the farmer of a coamil obtains posts as byproduct of opening shifting cultivation plots and uses them in the construction or repairing of their house or to establish or repair cattle pens or fences for the orchards. Some tree species are of higher quality and are used to manufacture their own furniture or are marketable. Thus, farmers obtain materials for construction and in some cases sell them to the community.

Fustes are posts of poor quality, they are selected and set to dry for firewood or charcoal. In rural households, firewood is an efficient fuel, useful for hojas ni planta. Una vez que ha llenado sus canastos, los acarreará hasta el depósito o granero donde él y su familia dispondrán la cantidad que será para su subsistencia y la que destinarán para su venta.

\section{b) Ciclo del pastoreo de ganado}

Los rastrojos del maíz (tallos, hojas y olotes) tienen alto contenido nutricional forrajero, por esta razón se considera que su aprovechamiento es parte del sistema de producción del coamil. Cuanto más fresco esté el rastrojo mejor será su calidad, por lo cual el rastrojo se aprovecha inmediatamente después de que se cosecha el maíz.

Debido a que el usuario de un coamil no siempre es el propietario y no siempre tiene ganado, el uso del rastrojo requiere una negociación entre los actores involucrados en diversos escenarios; así, existen cuatro tipos de usuarios en la zona de estudio:

i) el usuario del coamil es propietario del terreno y tiene ganado. El rastrojo se aprovecha para alimentar su propio ganado.

ii) el usuario del coamil es propietario, pero no tiene ganado. En este caso se vende el forraje al ganadero y obtiene un ingreso económico. Los principales acuerdos suelen ser la renta de la parcela por temporada -con un precio fijo por hectárea-, o bien, un precio fijo por unidad de ganado que se alimenta en la parcela durante un periodo fijo de seis meses.

iii) el usuario del coamil no es propietario, pero tiene ganado. Al negociar con el propietario se establecen las condiciones sobre el uso del coamil y los rastrojos, el acuerdo puede ser monetario (i.e. un precio establecido) o un acuerdo de intercambio.

iv) el usuario del coamil no es propietario y no tiene ganado. En estos casos el interés del usuario es únicamente el maíz, por lo cual el rastrojo pertenece al propietario del terreno.

En cualquier caso, el rastrojo siempre representa un bien directo o un ahorro para el propietario del terreno. Existen dos modalidades principales para el aprovechamiento del rastrojo: 1) cuando el rastrojo entero o molido se traslada al lugar donde está el ganado (ex situ), o bien, 2) cuando el ganado se traslada al coamil donde está el forraje para que lo consuma allí (in situ). Según nuestras observaciones en campo, el 
food preparation and to satisfy other needs such as an environment heater or fuel for firewood boilers. Charcoal is also used to cook food. Unlike gas or conventional stoves used in households, firewood and charcoal are available resources, not only from slashing a coamil but also from the natural forests dynamics.

In recent years, the husk that covers the corn has had more market demand. Under this scenario, some coamil farmers have the opportunity to optimize the process and the moment of harvest because leaf marketers provide personnel and equipment to harvest the ear corn, in exchange they are allowed to cut, pack and take the husks. In response to this increasing demand, some owners have seen an opportunity as an additional source of income. Eventually, other crops associated to maize are obtained, such as beans and squash, and other by-products such as corn smut, squash flowers and seeds, wild tomatillo among others.

In the whole production process of the coamil, the main investment is labor. Costs related to the coamil are for purchasing supplies, such as seed; in some cases the use of herbicides and fertilizers purchased and applied only once a year; contrarily, the products obtained from the agricultural system of the coamil constantly provide food to the households throughout the year.

\section{Design of the choice experiment}

After identifying the stages of the shifting cultivation system (e.g. coamil), the choice experiment was designed, a useful tool to estimate compensations in light of a shift on the welfare changes as a result of restrictions on the practice of some economic activities associated to forest degradation.

\section{Attributes and levels of the choice experiment}

The attributes and relevant levels were determined after several visits to the study area, interviews with forestry technicians with experience in the study area, local authorities of ejidos, personnel from JIRA and professors from the Universidad de Guadalajara who carry out research in the study area. Several focus groups were made with relevant population to determine the comprehension and accuracy of the proposed scenario in the experiment. aprovechamiento in situ permite utilizar los residuos del maíz como alimento, además de impedir el rápido crecimiento de otros arbustos que tienden a recubrir la superficie evitando que se establezca la maleza, además otra ventaja adicional es que el estiércol, sirve de abono para el nuevo ciclo de cultivo.

\section{c) Aprovechamiento de otros materiales}

La técnica de coamiles es un medio de subsistencia para familias rurales debido a que todo el ciclo de un coamil significa aprovechamiento de recursos y obtención de productos en cada etapa. Esto se traduce en la satisfacción de las necesidades básicas de un núcleo familiar como alimentación y vivienda y ante el excedente de productos puede significar ingresos monetarios. Por ejemplo, el usuario del coamil obtiene postes producto de la apertura y los utiliza en la construcción o reparación de su vivienda o para el establecimiento o reparación de corrales para el ganado, o bien, para el cercado de huertos. Algunas especies de árboles tienen mayor calidad y se utilizan para la fabricación de muebles propios o comercializables. De esta manera, el usuario obtiene materiales de construcción, y en algunos casos los vende en la comunidad.

Los fustes son postes de baja o mala calidad, se seleccionan y se ponen a secar para leña o carbón. En hogares rurales la leña es un combustible eficiente, útil para la preparación de alimentos y para satisfacer otras necesidades como calentador de ambientes o combustible para calentadores de leña. El carbón también se utiliza con frecuencia para cocinar alimentos. A diferencia del gas y de las estufas convencionalmente utilizadas para el hogar, la leña y el carbón son recursos disponibles, no solo provenientes del desmonte de un coamil, sino también de la dinámica natural de los bosques.

En los últimos años la hoja de maíz que envuelve la mazorca ha tenido mayor demanda en el mercado. Ante este escenario algunos usuarios de coamil tienen la oportunidad de optimizar el proceso y tiempo de cosecha debido a que los comercializadores de hojas facilitan personal $y$ equipo para piscar el maíz, a cambio se les permite cortar, empacar y llevarse la hoja. Ante esta creciente demanda, algunos propietarios han visto una oportunidad como fuente de ingresos adicional. 
After determining the attributes and levels for the alternatives, a fractional factorial design was used to estimate more efficiently effects of the relevant attributes. The factorial design resulted $\left(1^{2 *} 4^{2}\right)$ in 16 choice sets for the forest conservation program. Each interviewee was presented with two pairs of alternatives, one of them corresponded to a combination of the conservation program, the second one was the current situation, or the status quo program. Table 1 shows the alternatives and levels included in the experiment.

A questionnaire was designed where the interviewees were asked the minimum willingness to accept annually in monetary units a compensation to forego practicing the traditional activities associated with forest degradation in exchange of using those plots in a conservation program. To reduce the tendency to exaggerate the associated compensation, the annual willingness to accept format (DAA, acronym in Spanish) of the interviewees, a text proposed by Bush, Hanley, Moro, and Rondeau (2013) was used to mitigate the compensation effects in an anticipated manner.
Otros productos que se obtienen eventualmente son cultivos asociados al maíz, como frijol y calabaza y otros productos derivados como el hongo de maíz, la flor de calabaza y su semilla, los tomatillos silvestres, entre otros.

En todo el proceso de producción en coamil, la principal y mayor inversión que se realiza es la fuerza de trabajo. Los costos relacionados con el coamil son por la compra de insumos como la semilla; en algunos casos el uso de herbicidas y fertilizantes que solo se adquieren y aplican una vez al año; en cambio, los productos que se obtienen del sistema agrícola del coamil abastecen de alimento a los hogares de manera constante y durante los doce meses del año.

\section{Diseño del experimento de elección}

Tras la identificación de las etapas del sistema agrícola roza-tumba-quema (i.e. coamil) se diseñó el ejercicio de experimentos de elección, una herramienta útil para estimar las compensaciones ante un cambio en el bienestar debido a variaciones (es decir, restricciones) en la práctica de algunas actividades económicas asociadas a la degradación forestal.

Table 1. Attributes and levels used in the model of choice experiments Cuadro 1. Atributos y niveles utilizados en el modelo de experimentos de elección

\begin{tabular}{|c|c|c|c|}
\hline Attribute / Atributo & Description / Descripción & Variable & Levels / Niveles \\
\hline SC Practice / Practicar rtq & $\begin{array}{l}\text { Hectares under shifting } \\
\text { cultivation SC / } \\
\text { Hectáreas para sembrar sistema } \\
\text { agrícola roza-tumba-quema (rtq) }\end{array}$ & SC / RTQ & $\begin{array}{c}4 \\
6 \\
8 \\
10\end{array}$ \\
\hline $\begin{array}{c}\text { Cattle grazing / } \\
\text { Pastoreo de ganado }\end{array}$ & $\begin{array}{c}\text { Cattle grazing in plots with tropical } \\
\text { dry forest vegetation where SC is } \\
\text { practiced / } \\
\text { Pastoreo de ganado en parcelas } \\
\text { con vegetación selva baja donde se } \\
\text { practica rtq }\end{array}$ & Cattle / Ganado & $\begin{array}{c}\text { No, Yes / } \\
\text { No, Si }\end{array}$ \\
\hline $\begin{array}{l}\text { Lumber products } \\
\text { (collection of posts } \\
\text { and firewood) / } \\
\text { Productos maderables } \\
\text { (recolección de postes } \\
\text { y leña) }\end{array}$ & $\begin{array}{l}\text { Collection of firewood and posts } \\
\text { in plots with lowland rainforest } \\
\text { vegetation where SC is practiced / } \\
\text { Recolección de leña y postes en } \\
\text { parcelas con vegetación selva baja } \\
\text { donde se practica rtq }\end{array}$ & L_P / P_M & $\begin{array}{c}\text { No,Yes / } \\
\text { No, Si }\end{array}$ \\
\hline $\begin{array}{l}\text { Annual compensation / } \\
\text { Compensación anual }\end{array}$ & $\begin{array}{l}\text { Payment for farmers participating in } \\
\text { the conservation program / } \\
\text { Pago para los campesinos que } \\
\text { participen en el programa de } \\
\text { conservación }\end{array}$ & $\begin{array}{l}\text { Compensation / } \\
\text { Compensación }\end{array}$ & $\begin{array}{l}4000 \text { pesos } \\
7000 \text { pesos } \\
10000 \text { pesos } \\
13000 \text { pesos }\end{array}$ \\
\hline
\end{tabular}


Text

In this questionnaire we are asking farmers how much are they willing to accept as compensation to estimate the amount that will be paid in the program.

The forest conservation program has a limited budget, so it can only be implemented if the total amount requested by the interviewed farmers is less or equal to the amount available for payments in this conservation program.

If the total amount of compensations requested by the interviewees is more than the amount of money available for payments in this conservation program, the program will not take place and all the farmers will continue practicing their activities as always.

\section{Sample}

The data used in this study is part of a larger project that analyzes bio-physical factors and opportunity costs associated to forest degradation in 32 ejidos located in the Junta Intermunicipal de Medio Ambiente de la Cuenca Baja del Río Ayuquila (JIRA).

In this study a random sample of farmers older than 18 years was selected to be interviewed in the summer of 2013. The sample was selected from official records provided by local authorities of 18 ejidos, so it could be representative in terms of the total number of farmers who sow maize under shifting cultivation system (coamil) in each locality.

A common characteristic between interviewees was that this agricultural system provides them with posts to build fences in the common area of the ejido or in their houses, wood for self-consumption and to sell, maize for self-consumption and fodder with the crop residues after the harvest to feed the cattle. Most of the interviewees do not have any so once the maize has been harvested, they lease their land to the minority of the farmers who have cattle so they can use the remains of the maize plant, charging a fixed tariff per season or unit of cattle during the 'dry' season in order to save the equivalent as to purchasing grass.

\section{The choice experiments method (CE)}

The preferences for different attributes of a forest conservation plan can be modeled with choice
Atributos y niveles del experimento de elección Los atributos y niveles relevantes se determinaron tras varias visitas a las localidades seleccionadas, entrevistas con técnicos forestales con experiencia en el área de estudio, autoridades locales de los ejidos, personal de JIRA y profesores de la Universidad de Guadalajara que desarrollan investigación en la zona de estudio. Se realizaron varias reuniones focales con la población relevante para determinar la comprensión y veracidad del escenario propuesto en el experimento. Tras determinar los atributos y niveles para las alternativas se utilizó un diseño factorial fraccionado para estimar con mayor eficiencia los efectos de los atributos relevantes. El diseño factorial resultó en $\left(2^{2 *} 4^{2}\right) 16$ conjuntos de elección para el programa de conservación forestal. A cada entrevistado se le presentó dos parejas de alternativas, una de ellas correspondía a una combinación del programa de conservación, la segunda era el no llevar a cabo el programa status quo. El Cuadro 1 muestra las alternativas y niveles incluidos en el experimento.

Se diseñó un cuestionario donde se preguntó a los entrevistados la mínima disposición para aceptar anualmente en unidades monetarias una compensación por renunciar al uso de las actividades tradicionales asociadas con la degradación forestal a cambio de dedicar esas parcelas a un programa de conservación. Para reducir la tendencia a exagerar la compensación asociada, el formato de disposición a aceptar (DAA) anual de los entrevistados, se utilizó un texto que permitiera mitigar los efectos de la compensación de manera anticipada propuesta por Bush, Hanley, Moro, y Rondeau (2013).

Texto

En este cuestionario estamos preguntando a los campesinos cuánto estarían dispuestos a aceptar como compensación para evaluar la cantidad que finalmente se pagará en el programa.

El programa de conservación forestal tiene un presupuesto limitado, así que solo podrá implementarse si la cantidad total que piden todos los campesinos entrevistados es menor o igual a la cantidad que se tiene disponible para pagar en este programa de conservación. 
experiments (CE). A conservation plan involves an intervention/restriction in the traditional use and consumption of natural resources. To valuate different attributes or characteristics of a forest conservation plan, this study implements the choice experiments where variations in the conservation plans are found, with different attributes among which the interviewee must select the one he prefers the most. The random utility maximization (RUM) model allows the presentation of options where each individual $i$ can choose among $j$ alternatives to obtain a utility $U_{i j}$. By choosing the alternative $j$ where $j=1 . . . J$ it is assumed that the individual chooses the one that maximizes his utility. This utility can be divided into two parts: $V_{i j}$ representing observable preferences of the individuals from their choices while $\varepsilon_{i j}$ would capture the non- observable characteristics that affect the utility of the individuals and are introduced as a random variable, thus the utility function can be broken down as follows:

$U_{i j}=V_{i j}+\varepsilon_{i j}$

When presenting the alternatives to the interviewees, the following expression is obtained:

$\left.\operatorname{Pr}\left\{U_{i k}>U_{i j}\right\rangle\right\}=\operatorname{Pr}\left\{V_{i k}-V_{i j}>\varepsilon_{i k}-\varepsilon_{i k}\right\} \forall j \neq k, j \in C$

The random variables are considered independent and identically distributed (i.i.d.), so the choices of the individuals $i$ can be expressed as:

$\left.\operatorname{Pr}\left(U_{i j}\right\rangle U_{i k}\right)=\frac{\exp ^{\beta^{\prime} x_{i j}}}{\sum_{j} \exp ^{\beta^{\prime} x_{i k}}}$

Where $x_{i j}$ represents a vector of variables and $\beta^{\prime}$ is a vector of parameters. The probability function scales the coefficients to obtain the variance in the unobservable part (random variables).

By maximizing the log-likelihood function (e.g. the probability function of the alternatives chosen by the individual) the probability to accept a compensation in exchange to cease using forest resources can be calculated through the following equation (Hensher, Rose, \& Greene, 2005; Train, 2003):

$L(\beta, \sigma)=\prod_{i} \prod_{j}\left(P_{i j}\right)$
Si la suma de las compensaciones que piden los entrevistados es mayor al dinero disponible para pagar en este programa de conservación, el programa no se llevará a cabo y todos los campesinos seguirán practicando sus actividades como siempre.

\section{Muestra}

Los datos utilizados en esta investigación son parte de un proyecto más grande en el que se analizan factores bio-físicos y costes de oportunidad asociados a la degradación forestal en 32 ejidos situados en la Junta Intermunicipal de Medio Ambiente de la Cuenca Baja del Río Ayuquila (JIRA).

En este estudio se realizó una muestra aleatoria de campesinos mayores de 18 años en el verano de 2013. La muestra se seleccionó a partir de registros oficiales proporcionados por las autoridades locales de 18 ejidos, de forma que fuera representativa en términos del total de productores que se dedican a la siembra de maíz bajo el sistema agrícola roza-tumbaquema (coamil) en cada localidad.

Una característica común entre los entrevistados fue, que a partir de este sistema agrícola los campesinos obtienen postes para construir vallas en el área común del ejido o en sus viviendas, leña para autoconsumo y también para venta, maíz principalmente para autoconsumo y tras la cosecha, los residuos que quedan del cultivo lo utilizan para alimentar al ganado. La mayoría de los entrevistados no tiene, de manera que, una vez cosechado el maíz rentan sus terrenos a la minoría de campesinos que sí poseen ganado para aprovechar los restos del maíz, cobrando una tarifa fija por temporada o por unidad de ganado durante el periodo de 'secas' y así ahorrar el equivalente a la compra de pasto.

\section{El método de los experimentos de elección (EE)}

Las preferencias ante variaciones en distintos atributos que componen un plan de conservación forestal pueden modelarse con experimentos de elección (EE). Un plan de conservación implica una intervención/ restricción en el uso y consumo tradicional de los recursos naturales. Para valorar distintos atributos o características de un plan de conservación forestal, este estudio aplica los experimentos de elección, donde se presentan variaciones en los planes de 


\section{Marginal willingness to accept}

The application of CE enables the estimation of the implicit prices for each attribute, that is to say, unitary variants of the concrete attribute, keeping the rest of the attributes constant. According to the generic model presented in equation (1), the representative component of the utility is given by $V_{j}$ for the $j$ alternative and can be represented as:

$V_{j}=\hat{\mathrm{I}}^{2}{ }_{0}+\hat{\mathrm{I}}^{2}{ }_{S C} \hat{\mathrm{I}}^{\prime \prime} \mathrm{SC}+\hat{\mathrm{I}}_{\text {Firewood }}^{2} \hat{\mathrm{I}}^{\prime \prime}$ Firewood +

$\hat{\mathrm{I}}^{2}$ Cattle $\hat{I}^{\prime \prime}$ Cattle $+\hat{\mathrm{I}}^{2}$ Compensation $\hat{\mathrm{I}}^{\prime \prime}$ Compensation

Where $\beta_{0}$ represents a parameter not associated to any attribute of the model and captures the mean effect of the unobservable factors in the model that affects the utility of the individuals; $\beta$ are the coefficients or weight of each attribute that will be estimated in the multinominal model and $\Delta$ corresponds to a one-unit variation of each attribute.

Finally, the willingness to accept (WTA) or marginal compensation of each attribute is obtained by dividing the estimated parameter of the attribute of interest by the monetary coefficient of compensation:

$W T A_{\text {marginal }}=\frac{\beta_{\text {attribute }}}{\beta_{\text {compensation }}}$

The treatment of the data was carried out by using version 15 of the statistical package StataCorp, 2017. Stata Statistical Software: Release 15. College Station, TX, USA: StataCorp LLC.

\section{Results}

One hundred twenty nine farmers were interviewed in 18 ejidos practicing the shifting cultivation system. The sociodemographic characteristics of the interviewed farmers in this study are presented in Table 2.

In the sample, the percentage of men is higher compared to the average percentage of men for the state of Jalisco, the mean value of members per household in the sample also exceeds the average statewide members per household. The same thing happens for the age variable, where the average age of the interviewees is approximately 50 years older than the average age registered for the population of Jalisco. In this way, the level of schooling in the conservación con distintos atributos entre los cuales, el entrevistado debe elegir el que más prefiere. El modelo de maximización de utilidad aleatoria (MUA), permite presentar opciones en las que cada individuo puede elegir entre alternativas para obtener una utilidad. Al elegir la alternativa con se asume que el individuo elige la que maximiza su utilidad. Esta utilidad puede dividirse en dos partes: representando las preferencias observables de los individuos a partir de sus elecciones mientras que capturaría las características no observables que afectan la utilidad de los individuos y se introducen como variable aleatoria, por tanto, la función de utilidad puede descomponerse de la siguiente manera:

$U_{i j}=V_{i j}+\varepsilon_{i j}$

Al representar las alternativas a los entrevistados se obtiene la siguiente expresión:

$\left.\operatorname{Pr}\left\{U_{i k}>U_{i j}\right\rangle\right\}=\operatorname{Pr}\left\{V_{i k}-V_{i j}>\varepsilon_{i k}-\varepsilon_{i k}\right\} \forall j \neq k, j \in C$

Las variables aleatorias se consideran independiente e idénticamente distribuidas (i.i.d.), de manera que las elecciones de los individuos pueden expresarse como:

$\left.\operatorname{Pr}\left(U_{i j}\right\rangle U_{i k}\right)=\frac{\exp ^{\beta^{\prime} x_{i j}}}{\sum_{j} \exp ^{\beta^{\prime} x_{i k}}}$

donde representa un vector de variables y es un vector de parámetros. La función de probabilidad escala los coeficientes para obtener la varianza en la parte no observable (variables aleatorias).

Al maximizar la función de verosimilitud (i.e. la función de probabilidades de las alternativas seleccionadas por los individuos) la probabilidad de aceptar una compensación a cambio de la renuncia al uso de recursos forestales puede calcularse mediante la siguiente ecuación (Hensher, Rose, \& Greene, 2005; Train, 2003):

$L(\beta, \sigma)=\prod_{i} \prod_{j}\left(P_{i j}\right)$

\section{Disposición marginal a aceptar}

La aplicación de EE permite estimar los precios implícitos de cada atributo, es decir, variaciones 
Table 2. Sociodemographic variables of the interviewees

Cuadro 2. Variables sociodemográficas de los entrevistados

\begin{tabular}{|c|c|c|c|}
\hline Variable & & $\begin{array}{l}\text { Sample / } \\
\text { Muestra }\end{array}$ & Jalisco* \\
\hline $\begin{array}{c}\text { Gender ( } \% \text { men) / } \\
\text { Género ( } \% \text { hombres) }\end{array}$ & 85 & 49 & \\
\hline $\begin{array}{l}\text { Age (years) / } \\
\text { Edad (años) }\end{array}$ & & 77 & 25 \\
\hline $\begin{array}{l}\text { Schooling (years) / } \\
\text { Educación (años) }\end{array}$ & 4 & 9.2 & \\
\hline $\begin{array}{l}\text { Members per household / } \\
\text { Miembros por hogar }\end{array}$ & 5.5 & 3.8 & \\
\hline
\end{tabular}

interviewed sample is below the average registered for the State with approximately five years less of formal education.

Figure 2 shows information about the main products that provide livelihood to the household of the farmers interviewed and it also enables the development of subsistence strategies based on markets. These products are usually obtained from the tropical dry forests and some of them (for example, posts, firewood and grass for cattle) are obtained when the forest is temporarily cleared to sow maize under shifting cultivation (e.g. coamil). Most of the households in the sample use medicinal plants (94\%), nopales (82\%) and posts for construction (79\%). Finally, $100 \%$ of the interviewed farmers practice shifting cultivation with a small amount or no cattle. In the local context, cattle usually serve as an investment in kind or a savings account that enables them to have quick money with their sales to the community to cover emergency expenses or family expenses (e.g. a sickness, a family party).

Medicinal plants are an important input for households, with a mean annual extraction of $30 \mathrm{~kg}$ per household. A percentage of this collection is for self-consumption and another is for sale; however, in our study, it has not been possible to determine what percentage corresponds to each usage. Firewood is the next mostly used product by the households, with an average of 48 annual loads. Farmers in the sample who have cattle are approximately one third (30\%), but only $9 \%$ of the interviewees take their cattle to graze in the common area, or in their unitarias del atributo concreto, manteniendo el resto de los atributos constantes. Según el modelo genérico presentado en la ecuación (1), el componente representativo de la utilidad viene dado por para la alternativa y puede representarse como:

$V_{j}=\hat{\mathrm{I}}^{2}{ }_{0}+\hat{\mathrm{I}}^{2}{ }_{R T Q} \hat{\mathrm{I}}^{\prime \prime} \mathrm{RTQ}+\hat{\mathrm{I}}_{\text {Leña }}^{2} \hat{\mathrm{I}}^{\prime \prime}$ Leña +

$\hat{\mathrm{I}}_{\text {Ganado }}^{2}$ Î"Ganado + Î $_{\text {Compensación }}^{2}$ I"Compensación

Donde representa un parámetro no asociado a ningún atributo del modelo y captura el efecto medio de factores no observados en el modelo que afecta la utilidad de los individuos; $\beta$ son los coeficientes, o peso de cada atributo que se estimarán en el modelo multinomial y $\Delta$, corresponde a variaciones unitarias de cada atributo.

Finalmente, la disposición a aceptar (DAA) o compensación marginal de cada atributo se obtiene dividiendo el parámetro estimado del atributo de interés por el coeficiente monetario de compensación:

$$
D A A_{\text {marginal }}=\frac{\beta_{\text {atributo }}}{\beta_{\text {compensación }}}
$$

El tratamiento de datos se hizo utilizando la versión 15 del paquete estadístico StataCorp, 2017. Stata Statistical Software: Release 15. College Station, TX, USA: StataCorp LLC.

\section{Resultados}

Se entrevistaron 129 campesinos de 18 ejidos que practican el sistema agrícola roza-tumba-quema. Las 


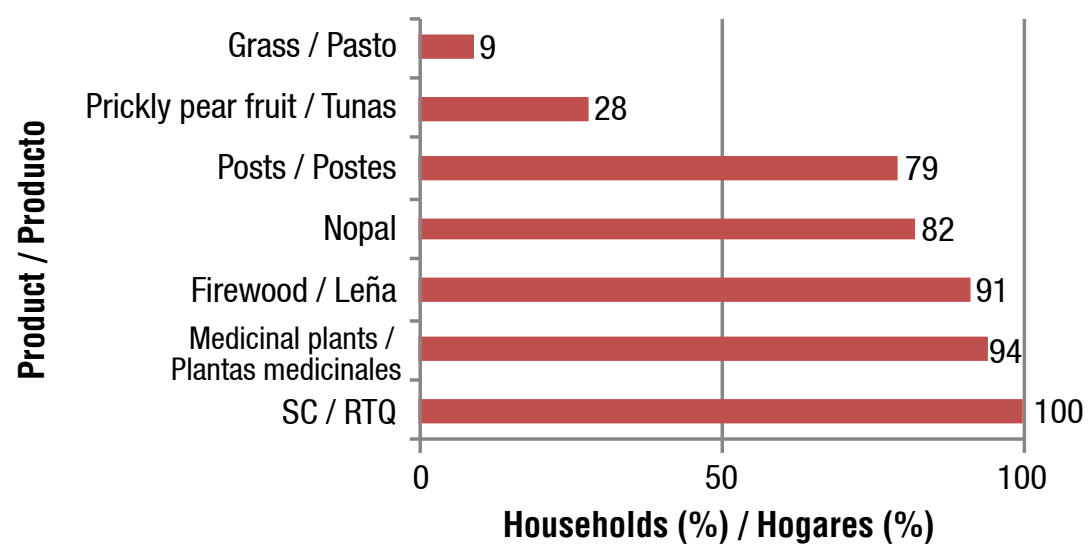

Figure 2. Proportion of households (\%) according to usage of forest products in the sample Figura 2. Proporción de hogares (\%) según uso de productos forestales en la muestra

property within the common area when it has been divided among ejidatarios. The rest of the interviewees obtain fodder from family members who permanently grow maize so they obtain fodder for cattle outside of the common areas.

Table 3 shows the average annual amount of collection of main forest products per household. Firewood is the product with higher monetary value according to the market price, which reveals its significance for rural households and a high local demand of firewood as a source of energy. The next product with higher value based on market prices corresponds to the posts for construction, which can reach up to 60 pesos per unit depending on the season. This range of prices (between 40 and 60 pesos) shows the effect of the parcelization of the commons area. The division of the territory has encouraged private use of the plots that used to be of common property and farmers have incentives to delimitate their plots with posts in which they establish pastures to lease their land to cattle owners and guarantee an additional income. Finally, the collection of prickly pear fruit and nopal is a temporary activity during the year (four months), it enables them to develop subsistence strategies in local markets because these are products with high demand in the region.

Results from the conditional logit model can be seen in Table 4. The values obtained cannot be directly interpreted because the scale unit of each attribute is different, however, the parameters have the expected signs. The sign indicates if the características sociodemográficas de los campesinos entrevistados en este estudio se presentan en el Cuadro 2.

En la muestra, el porcentaje de hombres es superior comparado al promedio del porcentaje de hombres para el estado de Jalisco, y también el valor medio de miembros por hogar en la muestra supera al promedio de miembros por hogar estatal. Lo mismo sucede para la variable edad, donde la edad promedio de los entrevistados es aproximadamente 50 años mayor a la edad promedio registrada para la población de Jalisco. Por otra parte, el nivel educativo de la muestra entrevistada está por debajo del promedio registrado para el estado, con aproximadamente cinco años menos de educación formal.

Las plantas medicinales son un insumo importante para los hogares, con una extracción media de $30 \mathrm{~kg}$ anuales por hogar. Un porcentaje de esta recolección es para autoconsumo y otro para venta; sin embargo, en nuestro estudio no ha sido posible determinar qué porcentaje corresponde a cada uso. La leña es el siguiente producto mayormente usado por los hogares, con un promedio de 48 cargas anuales. Los campesinos en posesión de ganado en la muestra son aproximadamente una tercera parte (30\%), pero solo $9 \%$ de los entrevistados declaró que lleva a pastar su ganado en bosques de área común, o bien, en su propiedad del área común cuando esta se ha fraccionado entre los ejidatarios. El resto de los entrevistados obtiene forraje de familiares que 
Table 3. Annual amount and monetary value of forest products per household. Cuadro 3. Cantidad y valor monetario anual de productos forestales por hogar.

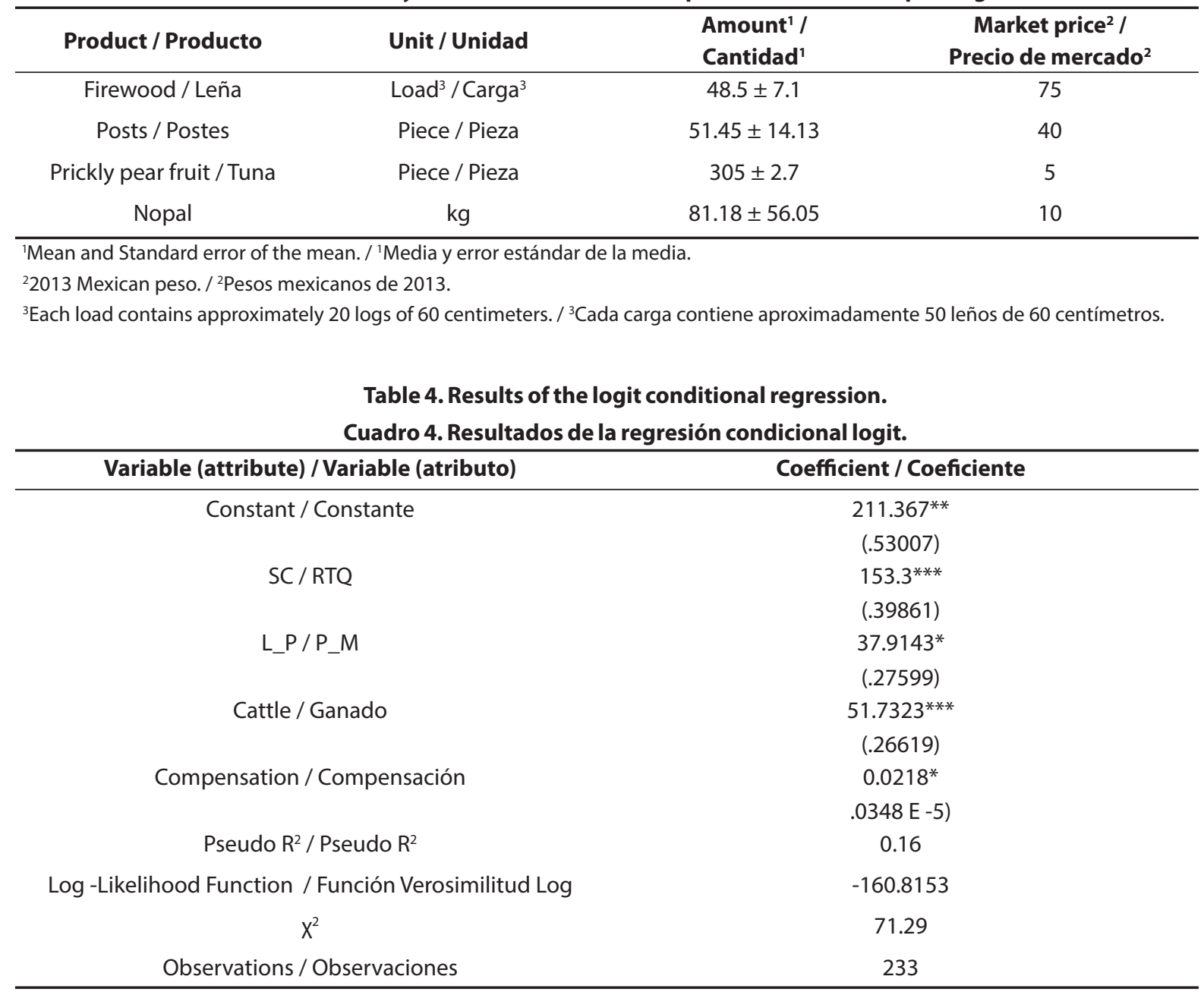

Standard error value in parenthesis / Valor del error estándar entre paréntesis

***, ***, Significant at a level of 1,5 and $10 \%$ respectively / ${ }^{* * *},{ }^{* *},{ }^{*}$ Significativo para un nivel del 1,5 y $10 \%$ respectivamente

McFadden's Pseudo-R² (1973). / Pseudo-R² McFadden (1973).

probability to choose an alternative increases or decreases when the value of the attribute increases. For example, the constant is positive and significant, suggesting that the interviewed farmers would obtain higher utility if a forest conservation plan is implemented whenever they receive a compensation payment. In general, the extraction of lumber products (firewood and posts), practicing cattle grazing and shifting cultivation are factors that increase the probability to choose an alternative. The coefficient of annual compensation is positive due to the compensation payment in exchange of ceasing the traditional management of land use if the conservation plan is implemented. se dedican al cultivo de maíz permanente, de esta manera no les falta alimento para ganado fuera de las áreas comunes.

El Cuadro 3 muestra las cantidades anuales promedio de recolección de los principales productos forestales por hogar. La leña resulta ser el producto con mayor valor monetario según su precio de mercado, lo que da cuenta de la importancia para los hogares rurales y de la alta demanda local de leña como fuente de energía. El siguiente producto de mayor valor con base en precios de mercado corresponde a los postes para construcción, que puede alcanzar hasta 60 pesos por unidad según la temporada. Este rango de precios (entre 40 y 60 
The model presents a reduced goodness of fit, although Pseudo R2 values close to 0.2 indicate high adjustment (McFadden, 1974). The coefficient of the log-likelihood function rejects the hypothesis of the slopes being cero at a significance of $5 \%$.

Marginal compensations of the attributes $L_{-} P$ (lumber products or firewood/posts), Cattle and SC are calculated from Table 4, and the confidence intervals of the attributes according to the preferences and the valuation of the interviewed farmers. The results are shown in Table 5. To obtain a $95 \%$ confidence interval, the Krinsky and Robb method (1986) was followed using 1000 extractions.

Values for Cattle and L_P attributes correspond to discrete changes (e.g. being able or not to collect lumber products -firewood/posts-, or being able or not to practice cattle grazing in the restriction plots) under a scheme of the conservation plan. For the SC attribute, values correspond to the mean compensation for not sowing a hectare under the agricultural system SC (shifting cultivation, i.e. coamil) due to a new 'environmental' usage by the conservation plan.

Table 6 shows the average of the minimum annual willingness to accept (WTA) per each ceased activity that increases forest degradation (e.g. results shown in table 5) it also shows the average net-benefits of these activities, estimations based on market prices (Netbenefit = income - costs). The results in the column'Net financial benefit' is within the range of values obtained in previous studies published by one of the authors (Borrego \& Skutsch, 2014) estimations based on market prices. The difference between values of both columns is because they correspond to estimations pesos) pone en evidencia el efecto que ha tenido la repartición de los ejidos en las áreas comunes. La división del territorio ha fomentado el uso privado de las parcelas que antes eran de propiedad común y los campesinos tienen incentivos para delimitar sus parcelas con postes en las que establecen pastizales para rentar su tierra a los propietarios de ganado y garantizar un ingreso adicional al hogar. Finalmente, la extracción de tuna y nopal es una actividad temporal al año (un cuatrimestre) que les permite desarrollar estrategias de subsistencia en los mercados locales porque son productos con alta demanda en la región.

Los resultados del modelo logit condicional pueden verse en el Cuadro 4. Los valores obtenidos no pueden interpretarse directamente porque la unidad de escala de cada atributo es distinta, sin embargo, los parámetros tienen los signos esperados. El signo indica si la probabilidad de elegir una alternativa aumenta o disminuye cuando el valor del atributo aumenta. Por ejemplo, la constante es positiva y significativa, sugiriendo que los campesinos entrevistados obtendrían mayor utilidad si se implementa un plan de conservación de bosques siempre que reciban un pago en compensación. En general, la extracción de productos maderables (leña y postes), practicar pastoreo de ganado y la práctica de agricultura roza-tumba-quema son factores que aumentan la probabilidad de elegir una alternativa. El coeficiente de la compensación anual es positivo debido al pago compensatorio a cambio de renunciar al manejo tradicional del uso del suelo en caso de que se implementara el plan de conservación.

Table 5. Marginal willingness to accept*

Cuadro 5. Disposiciones marginales a aceptar*

\begin{tabular}{cc}
\hline Variable (attribute) / Variable (atributo) & $\begin{array}{c}\text { Marginal willingness to accept ** / } \\
\text { Disposición a aceptar marginal** }\end{array}$ \\
\hline L_P / P_M & 1737.8 \\
Cattle / Ganado & $(1684.7 ; 1791.0)$ \\
SC / RTQ & 2300.7 \\
\hline
\end{tabular}

*2013 peso / * Pesos de 2013

** $95 \%$ Confidence intervals / ** Intervalos de confianza al $95 \%$ 
Table 6. Economic benefits vs financial benefits

Cuadro 6. Beneficios económicos vs beneficios financieros.

\begin{tabular}{|c|c|c|}
\hline Variable (attribute) / Variable (atributo) & $\begin{array}{l}\text { Economic benefit (WTA) 1,2/ } \\
\text { Beneficio económico (DAA) }{ }^{1,2}\end{array}$ & $\begin{array}{c}\text { Beneficio financiero neto }^{1,3} \text { / } \\
\text { Net financial benefit }{ }^{1,3}\end{array}$ \\
\hline L_P (firewood and posts) ${ }^{4} / P_{-} M\left(\right.$ (leña y postes) ${ }^{4}$ & 1740 & 2500 \\
\hline Cattle $^{5} /$ Ganado $^{5}$ & 2300 & 5500 \\
\hline $\mathrm{SC}^{6} / \mathrm{RTQ}^{6}$ & 7026 & 6500 \\
\hline
\end{tabular}

'2013 peso / 'Pesos de 2013.

${ }^{2}$ Minimum willingness to accept estimated with Choice Experiments (compensation - Table 5). /

${ }^{2}$ Mínima disposición a aceptar calculada con Experimentos de Elección (compensación - Cuadro 5).

${ }^{3}$ Net Benefit based on market prices (Net benefit= incomes - Costs). /

${ }^{3}$ Beneficio neto basado en precios de mercado (Beneficio neto $=$ Ingresos - Costes).

${ }^{4}$ Annual monetary value per extraction of lumber products (firewood and posts). /

${ }^{4}$ Valor monetario anual por extracción de productos maderables (leña y postes).

${ }^{5}$ Annual monetary value per unit (head of cattle). / ${ }^{5}$ Valor monetario anual por unidad (cabeza de ganado).

${ }^{6} \mathrm{Annual}$ monetary value per hectare of the shifting cultivation system. /

${ }^{6}$ Valor monetario por una hectárea del sistema agrícola roza-tumba-quema anual.

of a same attribute using different methods, hence different things are being measured. Whereas financial benefits are estimated from the minimum willingness to accept, that is to say, values expressed in monetary units showing the loss of welfare the farmers from the sample experience due to the restrictions the forest conservation plan might impose, thus capturing the social value of losing access to forest resources. In contrast, the estimation based on market prices shows the financial value indicating the proportion the usage of forest resources contribute to incomes so only the use value is captured.

\section{Discussion}

This study focused on measuring the relative contribution of the economic activities associated to forest degradation by estimating implicit prices. The main contribution of this study consists on the estimations of the minimum monetary compensation farmers would be willing to accept in exchange of participating in the conservation program, which involves ceasing some traditional activities with the aim of decreasing forest degradation levels and help decrease carbon emissions which contribute to climate change. This information is useful from a forest management perspective because it shows some social and economic implications that could be expected against international policy initiatives, such as the reducing emissions from deforestation and forest degradation (REDD+), which requires changes
El modelo presenta una bondad de ajuste reducido, aunque valores Pseudo $\mathrm{R}^{2}$ cercano al 0.2 indica un ajuste alto (McFadden, 1974). El coeficiente de la función de verosimilitud rechaza al $5 \%$ de significancia la hipótesis de que las pendientes del modelo sean cero.

A partir del Cuadro 4 se calculan las compensaciones marginales de los atributos P_M (productos maderables o leña/postes), Ganado y RTQ y los intervalos de confianza de los atributos de acuerdo con las preferencias y valoración de los campesinos entrevistados. Los resultados se muestran en el Cuadro 5. Para obtener los intervalos de confianza de $95 \%$ se siguió el método de Krinsky y Robb (1986) usando 1000 extracciones.

Los valores para los atributos Ganado y P_M corresponden a cambios discretos (i.e. poder o no poder recolectar productos maderables -leña/ postes-, o bien, poder o no poder practicar pastoreo de ganado en las parcelas de restricción) bajo un esquema del plan de conservación. Para el atributo RTQ corresponde a la compensación media por la renuncia de siembra de una hectárea bajo el sistema agrícola RTQ (i.e. coamil) debido a un nuevo uso 'ambiental' por el plan de conservación.

El Cuadro 6 muestra la media de la mínima disposición a aceptar (DAA) anual por la renuncia a cada actividad que aumenta la degradación forestal (i.e. resultados presentados en el Cuadro 5) y también muestra los beneficios netos medios de estas actividades calculadas con base en precios de 
and restrictions in the practice of some traditional activities (attributes) to reduce forest degradation.

According to the choice experiments the most important attribute for the interviewed farmers was the coamil (shifting cultivation). This result was consistent with answers to the debriefing questions of the questionnaire which were useful to verify the results from the choice experiment. We specifically asked respondents to state which one of the three attributes they had in mind when deciding their preferred option in the exercise. Approximately $58 \%$ of the interviewees responded that the main attribute they took into consideration to choose the selected alternative was the total amount of hectares they would have to give up if the conservation program was implemented. The practice of this low income agricultural system for subsistence is frequent among farmers of low socioeconomic level that live in tropical dry forests in developing countries (Amelung, T. \& Diehl, M., 1992; Myers, 1992), that is, attributes that characterize our study area (Borrego \& Skutsch, 2019; Morales-Barquero et al., 2015). Additionally, this result shows the dependence of low-income farmers that subsist from a low cost agricultural system. Furthermore, our results are different from those found by De Salvo, Cucuzza, Cosentino, Nicita, \& Signorello (2018) who applied the same method to identify the preferences of organic farmers in Sicily, and considered the total cultivated area among the attributes; however, their experiment was focused toward the preferences to adopt practices that would promote sustainable crops. The research by De Salvo et al. (2018) found that the use of organic matter during cultivation was the most important attribute for agricultural land conservation over the total cultivated area.

The attribute cattle was the next in importance. In our case, most of the interviewed farmers do not own cattle, but still all of them have incentives to sell the maize residues to cattle owners because they obtain an additional income by selling them and also because manure serves as natural fertilizer for the next crop cycle. Previous research has analyzed the advantages of cattle from the perspective of low income communities (Coomes, et al., 2008; Ickowitz, et al, 2017; Maraseni, Neupane, LopezCasero, \& Cadman, 2014). Even when the monetary mercado (Beneficio neto $=$ ingresos - costes). Los resultados de la columna 'beneficio financiero neto' están dentro del rango de valores obtenidos en estudios previos publicados por una de las autoras (Borrego \& Skutsch, 2014) estimaciones basadas en precios de mercado. La diferencia entre los valores de las dos columnas se debe a que corresponden a estimaciones de un mismo atributo utilizando métodos diferentes $\mathrm{y}$, por tanto, se miden cosas distintas. Mientras que los beneficios económicos se calculan a partir de la mínima disposición a aceptar, es decir, valores expresados en unidades monetarias que muestran la pérdida de bienestar que experimentarían los campesinos de la muestra por las restricciones que podrían imponer un plan de conservación forestal, de esta manera se captura el valor social de la pérdida del acceso a los recursos forestales. En cambio, el cálculo basado en precios de mercado arroja un valor financiero que indica la proporción que aporta el uso de recursos forestales a los ingresos, de manera que solo se capturan valores de uso.

\section{Discusión}

Este estudio se centró en la medición de la contribución relativa que tienen las actividades económicas asociadas a la degradación forestal mediante el cálculo de precios implícitos. La principal aportación de este estudio consiste en las estimaciones de la mínima compensación monetaria que los campesinos estarían dispuestos a aceptar a cambio de participar en un programa de conservación, que supone la renuncia a la práctica de algunas actividades tradicionales con el fin de reducir los niveles de degradación forestal y ayudar a la reducción de emisiones de carbono que contribuyen al cambio climático. Esta información es útil desde una perspectiva de la gestión forestal porque muestra algunas implicaciones sociales y económicas que se podrían esperar frente a las iniciativas de políticas internacionales, como la reducción de emisiones por deforestación y degradación forestal (REDD+), que requiere cambios o restricciones en la práctica de algunas actividades tradicionales (atributos) para reducir la degradación forestal.

De acuerdo con los experimentos de elección el atributo de mayor importancia para los campesinos entrevistados fue la práctica del 
income from selling cattle is materialized in the long term, rural households have low risk in the markets, low sunk costs that show a low discount rate enables them to wait for the time being until the cattle reaches the optimum growth to be sold in the local market, however, it is an assured income in the future; thus the advantages of raising cattle correspond to benefits in an economic sense rather in a financial sense because it gives tranquility and assurance to have an immediate income even though it is in the long term. Finally, the attribute of lumber product extraction -firewood and posts- turned out to be the third one with most significance to the farmers in the sample. Answering the questionnaires, farmers experienced slight difficulty to choose a favorite program when these attributes varied independently among alternatives (e.g. lumber extraction is allowed, but extraction of posts is prohibited or vice versa) this situation arose because the quality and structure of the trunk defines its final usage (post or firewood). The importance in the usage of firewood in the interviewed sample (92\% of the interviewees use it as main source of energy) shows a low level of socioeconomic development in the sample; on the other hand, extraction of posts has intensified with the division of common areas of the ejidos. The informal division of the ejidos entails privatization of the resources of common property which make the plots function with the characteristics of private property, that is why the extraction of posts is required to mark out the 'private' area of each farmer. Some innovative practices consist on using 'living fences', trees planted in the boundaries of the ejidos to serve as posts when they become mature trees, while the posts elaborated with cement are less frequent. The importance of non-lumber products as a source of livelihood and as a source of income is wide in the literature (Angelsen \& Wunder, 2003; Kar \& Jacobson, 2012; Sills, et al., 2003; Zenteno, et al., 2013).

Our results based on three attributes show some considerations to be taken into account by international initiatives; for example, the interviewed farmers suggest that a monetary payment (e.g. compensation), after giving up their traditional activities, would not allow them to have a livelihood coamil (sistema agrícola roza-tumba-quema). Este resultado fue consistente con las respuestas a preguntas formuladas al final del cuestionario que nos permitieron contrastar los resultados del experimento de elección. En concreto, preguntamos cuál era la importancia entre los tres atributos presentados en el ejercicio. Aproximadamente 58 $\%$ de los entrevistados respondió que el principal atributo que tomaban en cuenta para elegir la alternativa seleccionada fue la cantidad total de hectáreas a las que deberían renunciar en caso de implementarse el programa de conservación. La práctica de este sistema agrícola de bajos insumos para subsistencia es frecuente en campesinos de clase socioeconómica baja que habitan en bosques tropicales de países en desarrollo (Amelung, T. \& Diehl, M., 1992; Myers, 1992), es decir, atributos que caracterizan nuestra área de estudio (Borrego \& Skutsch, 2019; Morales-Barquero et al., 2015). Además, este resultado muestra la dependencia de campesinos de bajos recursos que subsisten a partir de un sistema agrícola de bajo coste. Por otra parte, nuestro resultado difiere de los resultados encontrados por De Salvo, Cucuzza, Cosentino, Nicita, \& Signorello (2018) en el que se aplicó el mismo método para identificar las preferencias de agricultores orgánicos en Sicilia, considerando entre los atributos la superficie total cultivada; $\sin$ embargo, el experimento se dirigía a las preferencias para la adopción de prácticas que fomentaran cultivos sostenibles. La investigación de De Salvo, et al. (2018) encontró que el uso de materia orgánica en el cultivo era el atributo de mayor importancia para la conservación del suelo agrícola por encima de la superficie total cultivada.

El atributo ganado fue el siguiente en importancia. En este caso, la mayoría de los campesinos entrevistados no son propietarios de ganado, aun así, todos ellos tienen incentivos para vender los residuos del maíz a los dueños de ganado porque obtienen un ingreso adicional al venderlos y también porque el estiércol cumple la función de abono natural para el próximo ciclo de cultivo. Investigaciones previas han analizado las ventajas del ganado desde una perspectiva de las comunidades de bajo ingreso (Coomes, et al., 2008; Ickowitz, et al, 2017; Maraseni, Neupane, Lopez- 
for the next year or assure a constant source of energy against the possible shortage of firewood or simply against the disadvantage of running out of money after using the money received as compensation which could have been wasted in irrelevant expenses in less than a year and would have run out almost immediately.

Another observation during field work has to do with the socioeconomic characteristics of the farmers that practice this agricultural system, such as average age (more than 70 years), low schooling level and conditions of poverty, which show an agricultural system in which labor is the main input, it does not generate richness although it guarantees family maintenance for a year. It is possible that this traditional practice would decrease in the following years due to the migration of new generations to the big cities in search of better job opportunities and life conditions.

Forest resources provide important services to society, however, when the alternative consists on preserving the forests to generate (non)valuable social benefits or assure family subsistence it could seem like an unbalanced scale.

When attending the implications of national or international strategies involving the use and management of forest resources it is necessary to understand other variables related to the farmers perception and acceptance in order to understand the economic, social and distributive implications within rural forest communities (Agarwal, A., Grupta, K., (2005); Agarwal, 2001; Brännlund, Sidibe, \& Gong, 2009; Ostrom, 1990).

Our results are valid only for lowland forests.

\section{Conclusions}

The ongrowing interest of the international community to implement international policies to soften the impacts on climate change has encouraged the creation of new models based on land management and sustainable rural development. These interventions suggest changes in the traditional form of use and management of land in rural forest communities.

This research analyzed the relative contribution of the main economic activities that affect forest degradation by estimating implicit prices. It was
Casero, \& Cadman, 2014). Aun cuando los ingresos monetarios por la venta de ganado se materializan en el largo plazo, los hogares rurales tienen un riesgo bajo en los mercados, costes hundidos bajos que reflejan una tasa de descuento baja que les permite esperar el tiempo necesario hasta alcanzar el crecimiento óptimo del ganado para venderlo en el mercado local, sin embargo, es un ingreso futuro asegurado; de esta manera las ventajas de la crianza de ganado corresponden a beneficios en un sentido económico más que financiero, porque supone la tranquilidad y seguridad de tener un ingreso inmediato, aunque en el largo plazo. Finalmente, el atributo de extracción de productos maderables -leña y postes- resultó ser el tercero de más importancia para los campesinos de la muestra. En sus respuestas al cuestionario los entrevistados experimentaron cierta dificultad para elegir el programa preferido cuando estos atributos variaban de forma independiente entre las alternativas (e.g. se permite extracción de leña, pero la de postes está prohibida o viceversa) esta situación surgió porque la calidad y estructura del tronco es la que define el uso final (poste o leña). La importancia del uso de leña en la muestra entrevistada (92\% de los entrevistados la usan como principal fuente de energía) advierte un nivel de desarrollo socioeconómico bajo en la muestra; por otra parte, la extracción de postes se ha intensificado con la división de las áreas comunes de los ejidos. La división informal de los ejidos supone la privatización de recursos de propiedad común que hace funcionar las parcelas con características de propiedad privada, de ahí que se requiera la extracción de postes para delimitar el área 'privada' de cada campesino. Algunas prácticas innovadoras consisten en el uso de 'cercos vivos', árboles que se plantan en los límites del ejido para que reciba un uso de poste al convertirse en un árbol maduro, mientras que los postes elaborados con cemento son menos frecuentes. La importancia de productos no maderables como medio de subsistencia $y$ como fuente de ingresos es amplia en la literatura (Angelsen \& Wunder, 2003; Kar \& Jacobson, 2012; Sills, et al., 2003; Zenteno, et al., 2013).

Nuestros resultados basados en tres atributos, revelan algunas consideraciones a tomar en cuenta por las iniciativas internacionales; por ejemplo, los 
found that the main conditioning factor to give up shifting cultivation practices is the total amount of hectares that could not be sown under this system. As it is expected, this type of agriculture is for subsistence, so the decision to commit to carry out the restrictions of an environmental plan puts the family livelihood at risk. However, the monetary amount required as compensation to increase the probability of peasants willingness to participate (e.g. opportunity cost) can vary according to the method used for its estimation.

In particular, forest degradation is a complex process expanding in tropical dry forests affecting the functioning of environmental services, it is also an important generator of greenhouse gas emissions. In Mexico, the complexity is intensified with the traditional ownership of the land and the difficulty to understand the complexity of socioeconomic relations and the type of social groups among users (avecindados) and the landowners in the traditional rural system. Most of the forest area is managed by rural communities which are mostly classified with a mid or high marginalization level and to whom forests signify a basis of their livelihood. These forests provide energy (firewood), fencing poles, charcoal, food and several byproducts for the livelihood of forest communities.

The design of environmental policies should consider social perceptions of rural communities to understand the trade-offs from different conservation programs. The level of local social acceptance of international initiatives imposing restrictions on the use of forests to marginalized populations may condition the success of conservation measures when the effects on the social welfare are unknown, especially if we take as a starting point that the social benefits of forest conservation are higher than its costs.

\section{Acknowledgments}

The authors would like to thank the interviewed farmers in the study area for their contributions, to the Cátedra CONACYT - 1539 project and the funding received by the PAPIIT-UNAM IN300519 project.

End of English version campesinos entrevistados sugieren que un pago monetario (i.e. compensación), tras la renuncia a sus actividades tradicionales, no les permitiría asegurar un sustento para el siguiente ciclo, o bien, asegurar una fuente de energía constante ante una posible escasez de leña o sencillamente ante la desventaja de que el dinero recibido por una compensación monetaria podría destinarse a otros gastos irrelevantes en un periodo menor a un año y agotarse casi de inmediato.

Otra observación durante el trabajo de campo tiene que ver con las características socioeconómicas de los campesinos que practican este sistema agrícola, como la edad media (más de 70 años), el bajo nivel de escolaridad y las condiciones de pobreza, advierten un sistema agrícola en el que la fuerza de trabajo es el principal insumo, no genera riqueza, aunque sí garantiza el sustento familiar en un periodo de un año. Cabría la posibilidad de que esta práctica tradicional tienda a disminuir en los próximos años ante la migración de las nuevas generaciones a las grandes ciudades en búsqueda de mejores oportunidades laborales y condiciones de vida.

Los recursos forestales aportan servicios importantes para la sociedad, sin embargo, cuando la disyuntiva consiste en preservar los bosques para generar beneficios sociales (in)valuables o asegurar un sustento familiar podría parecer una balanza desequilibrada.

Al atender las implicaciones de estrategias nacionales o internacionales que se enfocan en el manejo y gestión de recursos forestales es preciso entender otras variables relacionadas con la percepción y aceptación de los campesinos para comprender implicaciones económicas, sociales y distributivas para y dentro de las comunidades rurales forestales (Agarwal, A., Grupta, K., (2005); Agarwal, 2001; Brännlund, Sidibe, \& Gong, 2009; Ostrom, 1990).

Nuestros resultados son válidos únicamente para bosques de selva baja.

\section{Conclusiones}

El creciente interés de la comunidad internacional por implementar políticas internacionales para atenuar los impactos del cambio climático ha incentivado la creación de nuevos modelos basados en el manejo del territorio y el desarrollo rural 


\section{References / Referencias}

Agarwal, A., \& Gupta, K. (2005). Decentralization and participation: the governance of common pool resources in Nepal's Teral. World Development. 33, 1101-1114.

Agarwal, B. (2001). Participatory exclusions, community forestry, and gender: an analysis for South Asia and a conceptual framework. Erratum. World Development. 29, 1623-1648.

Amelung, T., \& Diehl, M. (1992). Deforestation o tropical rain forests: economic causes and impact on development. Tübingen: J. C. B. Mohr.

Angelsen, A., \& Wunder, S. (2003). Exploring the forest poverty link: key concept issues, and research implications. Ocassional paper No. 40. CIFOR. Bagor, Indonesia.

Angelsen, A., Jagger, P., Babigumira, R., Belcher, B., Hogarth, N.,..., Wunder, S. (2014). Environmental income and rural livelihoods: a global-comparative analysis. World Development. 64(S1), S12-S28.

Borrego, A., \& Skutsch, M. (2014). Estimating the opportunity costs of activities that cause degradation in tropical dry forests: Impications for REDD+. Ecological Economics. 101, 1-9.

Borrego, A., \& Skutsch, M. (2019). How socio-economic differences between farmers affect forest degradation in western Mexico. Forests. 10(10), 1-17.

Brännlund, R., Sidibe, A., \& Gong, P. (2009). Participation to forest conservation in National Kabore Tambi Park in Southern Burkina Faso. Forests Policy and Economics. 11(7), 468-474.

Bush, G., Hanley, N., Moro, M., \& Rondeau, R. (2013). Measuring the local costs of conservation: a provision point mechanism for eliciting willingness to accept compensation. Land Economics. 89(3), 490-513.

Campbell, B. M., \& Luckert, M. (2002). Uncovering the hidden harvest: valuation methods for woodland and forest resources. (B. Campbell \& M. Luckert, Eds.). London, UK. New York, USA.: Earthscan Publications Ltd.

Coomes, O., Grimard, F., Potvin, C., \& Sima, P. (2008). The fate of the tropical forest: Carbon or cattle? Ecological Economics, 65(2), 207-212.

De Salvo, M., Cucuzza, G., Cosentino, S., Nicita, L., \& Signorello, G. (2018). Farmers' preferences for enhancing sustainability in arable lands: Evidence from a choice experiment in Sicily (Italy). New Medit. 17(4), 57-70.

Foley, J., Asner, G., Costa, M., Coe, M., DeFries, R.,..., Snyder, P. (2007). Amazonia revealed: Forest degradation and loss sustentable. Estas intervenciones sugieren cambios en la forma tradicional del uso y manejo de la tierra en las comunidades rurales forestales.

En esta investigación se analizó la contribución relativa de las principales actividades económicas que afectan la degradación forestal a partir del cálculo de precios implícitos. Se encontró que el principal factor condicionante para renunciar al sistema agrícola roza-tumba-quema es la cantidad total de hectáreas que no podrán sembrarlas bajo este sistema. Como es de esperarse, este tipo de agricultura es para subsistencia, por tanto, la decisión de comprometerse a cumplir las restricciones de un plan ambiental pone en riesgo el sustento familiar. Sin embargo, la cantidad monetaria requerida como compensación para aumentar la probabilidad de que los campesinos acepten participar (i.e. coste de oportunidad) puede variar según el método aplicado para su estimación.

En particular, la degradación forestal es un proceso complejo que se expande en bosques tropicales y que tiene relevancia para el funcionamiento de servicios ambientales, además de ser un importante generador de emisiones de gases de efecto invernadero. En México, esta complejidad se agudiza con la estructura tradicional de la titularidad de la tierra y las dificultades en comprender la complejidad de las relaciones socioeconómicas y los tipos de grupos sociales entre los usuarios (avecindados) y los propietarios de la tierra en el sistema rural tradicional. La mayor parte de la superficie forestal está manejada por comunidades rurales que en su mayoría están clasificadas con un nivel medio o alto de marginación y para las que los bosques significan su fuente de trabajo y medio de vida. A partir de estos recursos naturales, estas comunidades se abastecen de energía (leña), postes para construcción, material para la producción de carbón, alimentos y otros productos fundamentales para la subsistencia.

Es pertinente que el diseño de políticas ambientales pueda integrar las percepciones sociales y económicas de las comunidades rurales para conocer los trade-offs entre distintas medidas en los planes de conservación. El grado de aceptación local ante estas medidas internacionales que restringen el uso de los bosques en sociedades marginadas podría condicionar el éxito de las medidas de conservación 
of ecosystem goods and services in the Amazon Basin. The Ecological Society of America. Frontiers in Ecology and the Environment. 5(1), 25-32.

Food and Agriculture Organization (FAO). (2010). Evaluacion de los recursos forestales mundiales 2010. Informe principal. (GreenInk, Ed.). Roma, Italia: Departamento Forestal de la FAO.

Hensher, D., Rose, J., \& Greene, W. (2005). Applied choice analysis. (D. Hensher, J. Rose, \& W. Greene, Eds.). United Kindom.

Hosonuma, N., Herold, M., De Sy, V., De Fries, R., Brockhaus, M.,..., Romijn, E. (2012). An assessment of deforestation and forest degradation drivers in developing countries. Environmental Research Letters. 7(4), 1-12.

Ickowitz, A., Sills, E., \& De Sassi, C. (2017). Estimating Smallholder Opportunity Costs of REDD+: A pantropical analysis from households to carbon and back. World Development. 95, 15-26.

Insituto de Información Estadística y Geográfica de Jalisco (IIEG). (2010). Índice municipal de medio ambiente.

Johannesen, A. B. (2005). Wildlife conservation policies and incentives to hunt: an empirical analysis of illegal hunting in western Serengeti, Tanzania. Environment and Development Economics. 10(3), 271-292.

Kar, S., \& Jacobson, M. (2012). NTFP income contribution to household economy and related socio-economic factors: Lessons from Bangladesh. Forest Policy and Economics. 14, 136-142.

Kissinger, G., Herold, M., \& Sy V. De. (2012). Drivers of deforestation and forest degradation: A synthesis repor for REDD+ Policymakers. Vancouver, Canada.

Krinsky, I., \& Robb, L. (1986). On approximating the statistical properties of elasticities. The Review of Economics and Statistics. 68(4), 715-719.

Maraseni, T., Neupane, P., Lopez-Casero, F., \& Cadman, T. (2014). An assessment of the impacts of the REDD+ pilot project on community forests user groups (CFUGs) and their commnity forests in Nepal. Journal of Environmental Management, (136), 37-46.

McFadden, D. (1974). Conditional logit analysis of qualitative choice bahavior. In Frontiers in econometrics. 105-142. New York, US: Academic Press.

McShane, T., \& Wells, M. (2004). Getting biodiversity projects to work: towards nore effective conservation and cuando se desconoce el efecto para el bienestar de la sociedad si se acepta a-priori que los beneficios sociales de la conservación forestal superan su coste.

\section{Agradecimientos}

Las autoras agradecen la participación de los productores entrevistados en la zona de estudio, al proyecto Cátedra CONACyT - 1539 y al financiamiento recibido del proyecto PAPIIT-UNAM IN300519.

\section{Fin de la versión en Español}

development. (T. McShane \& M. Wells, Eds.). New York, US: Columbia University Press.

Morales-Barquero, L., Borrego, A., Skutsch, M., Kleinn, C., \& Healey, J. R. (2015). Identification and quantification of drivers of forest degradation in tropical dry forests: a case study in Western Mexico. Land Use Policy. 49, 296309.

Myers, N. (1992). Tropical forests: The policy challenge. The Environmentalist. 12(1), 15-27.

Ostrom, E. (2009). Governing the commons: The evolution of Institutions for Collective Actions (Canto Classics). Cambridge: Cambridge University Press.

Sills, E., Lele, S., Holmes, T., \& Pattanayak, S. (2003). Nontimber forest products in the rural household economy. En: Sills, Erin O.; Abt, Karen Lee, (eds). Forests in a market economy. Dordrecht, The Netherlands: Kluwer Academic Publishers. Pp. 259-281.

Skutsch, M., Paneque-Gálvez, J., Ghilardi, A., Balderas Torres, A., Morfin-Rios,..., Ross, D. (2017). Adapting REDD+ policy to sink conditions. Forest Policy and Economics. 80, 160-166.

Train, K. (2003). Discrete choice methods with simulation. (K. Train, Ed.). New York, US: Cambdrige University Press.

Vedeld, P., Angelsen, A., Bojö, J., Sjaastad, E., \& Kobugabe, G. (2007). Forest environmental incomes and the rural poor. Forest Policy and Economics. 9(7), 869-879.

Zenteno, M., Zuidema, P., de Jong, W., \& Boot, R.G.A. (2013). Livelihood strategiesand Forest dependes: New insights from Bolivian forest communities. Forest Policy and Economics. 26, 12-21. 